Published in final edited form as:

J Nat Prod. 2017 January 27; 80(1): 220-224. doi:10.1021/acs.jnatprod.6b01153.

\title{
(-)-Neocaryachine, an Antiproliferative Pavine Alkaloid from Cryptocarya laevigata, Induces DNA Double-Strand Breaks
}

\author{
Yuki Suzuki ${ }^{\dagger}$, Yohei Saito ${ }^{\dagger}$, Masuo Goto ${ }^{\star}, \neq$, David J. Newman ${ }^{\S}$, Barry R. O’Keefe ${ }^{\perp, \|}$, Kuo-

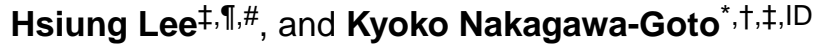 \\ †School of Pharmaceutical Sciences, College of Medical, Pharmaceutical and Health Sciences, \\ Kanazawa University, Kanazawa, 920-1192, Japan \\ ¥Natural Products Research Laboratories, UNC Eshelman School of Pharmacy, University of \\ North Carolina at Chapel Hill, Chapel Hill, North Carolina 27599-7568, United States \\ $\S N I H$ Special Volunteer, Wayne, Pennsylvania 19087, United States \\ ${ }^{\perp}$ Natural Products Branch, Developmental Therapeutics Program, Division of Cancer Treatment \\ and Diagnosis, $\mathrm{NCl}$ at Frederick, Frederick, Maryland 21702-1201, United States \\ "Molecular Targets Laboratory, Center for Cancer Research, National Cancer Institute, NCI at \\ Frederick, Frederick, Maryland 21702-1201, United States \\ "Lineberger Comprehensive Cancer Center, University of North Carolina at Chapel Hill, Chapel \\ Hill, North Carolina 27599-7295, United States \\ \#Chinese Medicine Research and Development Center, China Medical University and Hospital, 2 \\ Yuh-Der Road, Taichung, 40447, Taiwan
}

\section{Abstract}

Twelve benzylisoquinoline alkaloids, including pavine and phenanthroindolizidine types, were isolated from a MeOH/ $\mathrm{CH}_{2} \mathrm{Cl}_{2}$ extract of Cryptocarya laevigata (stem bark) through bioactivityguided fractionation for antitumor effects. Selected compounds were evaluated for antiproliferative activity against five human tumor cell lines, including a multidrug-resistant subline. Since more common 2,3,8,9-tetrasubstituted pavine alkaloids, such as crychine (3), exhibit very mild or no cytotoxicity, this compound type has not been well investigated for antitumor activity. Thus, this report is the first discovery of a 7-hydroxylated pavine alkaloid, (-)-neocaryachine (1), to demonstrate strong antiproliferative activity, with $\mathrm{IC}_{50}$ values of 0.06 to $0.41 \mu \mathrm{M}$ against five tested tumor cell lines, including an MDR subline. Further mechanism of action studies revealed that 1 impacts the cellular S-phase by inducing DNA double-strand breaks.

\footnotetext{
*Corresponding Authors. Phone (M. Goto): +1-919-843-6325. goto@med.unc.edu. Phone (K. Nakagawa-Goto): +81-76-264-6305. kngoto@p.kanazawa-u.ac.jp.

ORCID

Kyoko Nakagawa-Goto: 0000-0002-1642-6538

ASSOCIATED CONTENT

Supporting Information

The Supporting Information is available free of charge on the ACS Publications website at DOI: 10.1021/acs.jnatprod. $6 \mathrm{~b} 01153$.

${ }^{1} \mathrm{H}$ and ${ }^{13} \mathrm{C}$ NMR data, HRMS, and optical rotations for the isolated compounds (PDF)

The authors declare no competing financial interest.
} 


\section{Graphical Abstract}
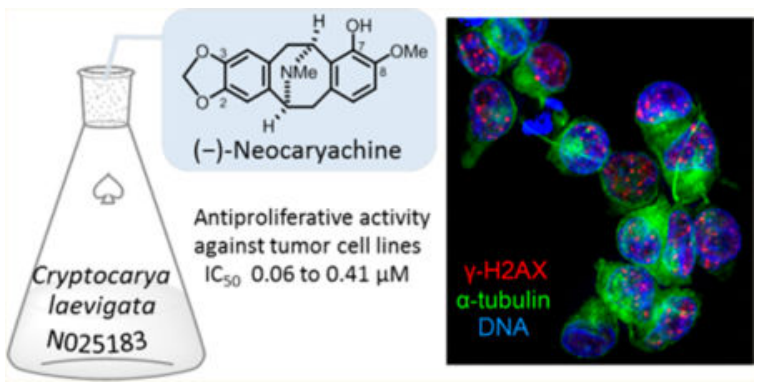

Rainforests are great treasure houses of biodiversity. ${ }^{1,2}$ Although they cover only about $6 \%$ of the earth's land surface, almost half of all plant species live in rainforest areas. ${ }^{3}$ The diversity in plants should also support a large variety of bioactive natural products. It is known that plants were among the first sources of drugs, and they still serve as an important source of modern medicines. ${ }^{4}$ Plant-derived natural products have contributed immensely to the area of cancer chemotherapeutics, e.g., paclitaxel, vinca alkaloids (vinblastine and vincristine), podophylltoxin analogues (etoposide and teniposide), and topotecan derived from camptothecin. According to a recent report, $583 \%$ of new chemical entities for anticancer agents have been derived from natural products per se, during the time frame of 1981 to 2014.

In the course of our research focused on the discovery of antitumor natural products from rainforest plants, a $\mathrm{CH}_{3} \mathrm{OH} / \mathrm{CH}_{2} \mathrm{Cl}_{2}$ (1:1) extract (NCI extract ID: N025183) from the rainforest plant Cryptocarya laevigata (stem bark) showed potent antiproliferative activity against several human tumor cell lines (Table S1, Supporting Information). The genus Cryptocarya belongs to the family Lauraceae and produces multiple secondary metabolites, such as lactones, a-pyrones, flavonoids, chalcones, and alkaloids. ${ }^{6-25}$ These chemical components show diverse bioactivities, including nitric oxide inhibitory activity, ${ }^{7}$ glucose transport inhibitory effects, ${ }^{8}$ cytotoxicity, ${ }^{8-11}$ antimicrobial activity, ${ }^{11}$ and dengue virus NS5 polymerase inhibitory properties, ${ }^{12}$ as well as anti-inflammatory, ${ }^{13}$ antioxidant, antiplasmodial, ${ }^{25}$ and cholinesterase inhibitory activities. ${ }^{26}$ Among over 350 species in the genus Cryptocarya, phytochemical research on $C$. laevigata has not been reported, except for one article published in $1978 .^{27}$

The crude extract of N025183 (9.8 g), provided by the NCI, was partitioned between EtOAc and water. The EtOAc extract was separated by silica gel column chromatography and preparative TLC techniques to give six known pavine alkaloids, (-)-neocaryachine (1) ${ }^{28}$ (-)-isocaryachine $(\mathbf{2}),{ }^{29}(-)$-crychine $(\mathbf{3}),{ }^{30}(-)$-eschscholtzine- $N$-oxide (4), ${ }^{31,32}(-)$ norargemonine (5), ${ }^{33,34}$ and (-)-bisnorargemonine (6), ${ }^{33,35}$ as well as a phenanthroindolizidine alkaloid and (-)-13aa-antofine ${ }^{36}$ together with their biosynthetic intermediates, (+)- $\mathrm{N}$-demethylphyllocaryptine, ${ }^{37}$ (+)-cinnamolaurine, ${ }^{38-40}(+)-\mathrm{N}$ methylcoculaurine, ${ }^{41}$ and (-)-reticuline. ${ }^{39,40}$ The structures of all isolated compounds were identified based on various NMR spectroscopic and HRMS data analyses, and their spectroscopic data agreed with published values. We evaluated five (1-5) of the six pavine alkaloids isolated from $C$. laevigata for antiproliferative activity against five human tumor 
cell lines, A549 (lung carcinoma), MDA-MB-231 (triple-negative breast cancer), MCF-7 (breast cancer), KB (originally isolated from epidermoid carcinoma of the nasopharynx), and vincristine-resistant KB-subline KB-VIN showing multidrug resistance (MDR) phenotype with overexpression of P-glycoprotein (Pgp) (Table 1).

It is generally believed that pavine alkaloids are noncytotoxic at a micromolar concentration; thus, little attention has been given to the antiproliferative activity of such alkaloids from the family Lauraceae. Instead, in this same family, phenanthroindolizidine-type alkaloids, which were isolated together with pavine alkaloids, demonstrated significant cytotoxicity with submicromolar $\mathrm{IC}_{50}$ values. ${ }^{42}$ Surprisingly, among the five pavine alkaloids tested in this study, (-)-neocaryachine (1) exhibited remarkable antiproliferative activity with $\mathrm{IC}_{50}$ values of less than $0.5 \mu \mathrm{M}$ against all tested tumor cell lines, even the MDR phenotype. (-)Isocaryachine (2) also potently inhibited the tumor cell growth, although its activity was lower than that of $\mathbf{1}$. The results indicated that a hydroxyl group at the $\mathrm{C}-7$ position is a crucial factor for the antiproliferative activity. On the basis of a comparison of compounds 3 and $\mathbf{4}$, an $\mathrm{N}$-oxide resulted in the loss of activity. Because no antiproliferative activity was observed for compound $\mathbf{5}$, a methylenedioxy moiety in ring A might be important for an antiproliferative effect. Interestingly, all compounds tested in this study were not substrates of P-gp, because the compounds suppressed chemosensitive (KB) and MDR (KB-VIN) cell growth at the same concentrations. However, many alkaloids, such as paclitaxel (PXL) and vincristine (VIN), are substrates of the ABC transporters expressed in MDR cancer cells, resulting in poor outcomes in cancer chemotherapy.

To understand the mechanism of action for the antiproliferative activity of these potent pavine alkaloids, the effects of compounds $\mathbf{1}$ and $\mathbf{3}$ on cell cycle progression in KB-VIN cells were initially examined using flow cytometry. As shown in Figure 1, at $0.3 \mu \mathrm{M},(-)-$ neocaryachine (1) had no effect after $24 \mathrm{~h}$, while some cells accumulated in the sub-G1 phase after $48 \mathrm{~h}$, suggesting apoptotic induction. In contrast, cells accumulated in the $\mathrm{S}$ phase in response to treatment with 3 or $10 \mu \mathrm{M} \mathrm{1}$, demonstrating that compound 1 impacted $\mathrm{S}$ phase progression, such as induction of DNA damage or inhibition of DNA duplication. Compound 3 showed no effects on the S phase, although sub-G1 was increased after $48 \mathrm{~h}$ of treatment at $20 \mu \mathrm{M}$. 5-Fluorouracil (5-FU) and combretastatin A-4 (CA-4) were used as controls for induction of cell cycle arrest in the $\mathrm{S}$ and $\mathrm{G} 2 / \mathrm{M}$ phases, respectively.

To further confirm the effects of $\mathbf{1}$ on the $\mathrm{S}$ phase, $\mathbf{1}$-treated KB-VIN cells were labeled with antibodies to $\mathrm{a}$-tubulin together with $\gamma$-H2AX, a biomarker for DNA double-strand breaks (DSBs), and 4',6-diamidino-2-phenylindole (DAPI) for labeling DNA (Figure 2). The $\gamma$ $\mathrm{H} 2 \mathrm{AX}$-positive nuclei were detectable in the cells treated with $0.3 \mu \mathrm{M} \mathrm{1}$, while they were unclear in the control cells (DMSO). The intensity of $\gamma$-H2AX signals and numbers of $\gamma$ $\mathrm{H} 2 \mathrm{AX}$-positive nuclei were dramatically increased when cells were treated with $\mathbf{1}(3 \mu \mathrm{M})$, suggesting that DSBs were induced by $\mathbf{1}$ in a concentration-dependent manner. Nuclear fragmentation was also observed in the compound-treated cells, suggesting apoptotic induction. In addition, abnormal morphology of microtubules was observed when cells were treated with 1 at $3 \mu \mathrm{M}$. No obvious $\gamma-\mathrm{H} 2 \mathrm{AX}$ signal or defects in microtubule morphology were observed in the cells treated with $\mathbf{3}$. These immunostaining results were consistent with the results of the cell cycle analysis showing an impact on the $\mathrm{S}$ phase. 
In summary, we have shown for the first time that the antiproliferative pavine alkaloid $\mathbf{1}$ impacts the cell cycle in the S phase by inducing DSBs and resulting in the induction of apoptosis.

\section{EXPERIMENTAL SECTION}

\section{General Experimental Procedures}

Optical rotations were measured on a JASCO P-2200 digital polarimeter. NMR spectra were recorded on JEOL JMN-ECS400 and JMN-ECA600 spectrometers with tetramethylsilane as an internal standard. Chemical shifts are expressed as $\delta$ values. HRMS data were obtained on a JMS-SX102A (FAB) or JMS-T100TD (DART) mass spectrometer. Analytical and preparative TLC were carried out on precoated silica gel $60 \mathrm{~F}_{254}$ and $\mathrm{RP}-18 \mathrm{~F}_{254}$ plates $(0.25$ or $1.0 \mathrm{~mm}$ thickness; Merck).

\section{Plant Material}

The stem bark of Cryptocarya laevigata was collected in the Philippines by D. D. Soejarto, E. Reynoso, E. Sagcal, and R. Edrada in March 1990 and identified by D. D. Soejarto. A voucher specimen (\#U44Z-7141) was deposited at the Smithsonian Institution (Washington DC, USA), and voucher extracts (N025183) are stored at the NCI (Frederick, MD, USA) and Kanazawa University (Kanazawa, Japan).

\section{Extraction and Isolation}

A $\mathrm{CH}_{3} \mathrm{OH} / \mathrm{CH}_{2} \mathrm{Cl}_{2}$ (1:1) extract of the bark of Cryptocarya laevigata $(9.8 \mathrm{~g})$ was partitioned with EtOAc and $\mathrm{H}_{2} \mathrm{O}$ to yield an EtOAc-soluble $(2.1 \mathrm{~g})$ and $\mathrm{H}_{2} \mathrm{O}$-soluble fractions. The EtOAc-soluble fraction was subjected to CombiFlash Rf MPLC (HPsil $120 \mathrm{~g}$ ) eluted with an $n$-hexane/EtOAc gradient system [5:1/1:1/1:5/0:1], then EtOAc/MeOH [9:1/4:1/0:1], to yield six fractions $\mathrm{A}-\mathrm{F}$.

Fraction E (1.2 g) was subjected to silica gel column chromatography eluted with $\mathrm{CH}_{2} \mathrm{Cl}_{2} /$ $\mathrm{MeOH}$ [50:1/30:1/10:1/5:1/1:1/0:1] to yield six fractions, E1-E6. Fraction E2 (175.2 mg) was purified by preparative TLC eluted with $\mathrm{CH}_{2} \mathrm{Cl}_{2}$ /acetone (1:3) to yield six fractions, E2a -E2f. Fraction E2c $(87.3 \mathrm{mg})$ was subjected to silica gel column chromatography eluted with $\mathrm{CH}_{2} \mathrm{Cl}_{2} / \mathrm{MeOH}$ [1:0/100:1/75:1/50:1/10:1/0:1] to yield (-)-crychine (3, $29.7 \mathrm{mg}$ ). Fraction E2d (44.8 mg) was purified by preparative TLC eluted with $\mathrm{CH}_{2} \mathrm{Cl}_{2} / \mathrm{MeOH}$ (5:1) to yield (-)-neocaryachine (1, $0.8 \mathrm{mg})$. Fraction E3 (100.4 mg) was subjected to silica gel column chromatography eluted with $\mathrm{CH}_{2} \mathrm{Cl}_{2} / \mathrm{MeOH}$ [1:0/50:1/40:1/30:1/20:1/10:1/1:1/0:1], then purified by preparative TLC eluted with $n$-hexane/acetone (1:3) to yield (-)-13aaantofine $(0.6 \mathrm{mg})$.

Fraction $\mathrm{F}$ (87.2 mg) was purified by preparative TLC eluted with $\mathrm{CH}_{2} \mathrm{Cl}_{2} / \mathrm{MeOH}$ (50:1) to yield six fractions, F1-F6. Fraction F2 $(46.8 \mathrm{mg})$ was purified by preparative TLC eluted with $\mathrm{CHCl}_{3} / \mathrm{MeOH}(10: 1)$ to obtain nine fractions, F2a-F2i. Fraction F2d $(5.0 \mathrm{mg})$ was then purified by preparative TLC eluted with $\mathrm{CHCl}_{3} / \mathrm{EtOH}$ (5:1) to yield (-)-isocaryachine (2, 3.4 $\mathrm{mg}$ ). Fraction F2f (2.4 mg) was purified by preparative TLC eluted with $\mathrm{CHCl}_{3} / \mathrm{MeOH}$ (5:1), then $n$-hexane/EtOAc (1:1), to yield (-)-norargemonine (5, $0.2 \mathrm{mg})$. Fraction F3 (9.5 
mg) was subjected to silica gel column chromatography eluted with $\mathrm{CH}_{2} \mathrm{Cl}_{2} / \mathrm{MeOH}$ [40:1/30:1/20:1/5:1/2:1/1:2/1:5/0:1] to yield seven fractions, F3a-F3g. Fraction F3c was (-)$N$-demethylphyllocaryptine $(0.6 \mathrm{mg})$. Fraction F3d $(2.5 \mathrm{mg})$ was purified by preparative TLC eluted with $\mathrm{CH}_{2} \mathrm{Cl}_{2} / \mathrm{MeOH}$ (5:1) followed by $\mathrm{CHCl}_{3} / \mathrm{EtOH}(5: 1)$ to yield (+)cinnamolaurine $(0.5 \mathrm{mg})$ and (-)-bisnorargemonine $(6,1.6 \mathrm{mg})$. Fraction F3e $(1.0 \mathrm{mg})$ was purified by preparative TLC eluted with $\mathrm{CHCl}_{3} / \mathrm{MeOH}$ (4:1) to yield four fractions, F3e1-F3e4. Fraction F3f (1.7 mg) was subjected to silica gel column chromatography eluted with EtOAc/MeOH [2:1/1:2/1:0] to yield five fractions, F3f1-F3f5. Fraction F3e2 and F3f4 were combined and purified by preparative TLC eluted with $\mathrm{CHCl}_{3} / \mathrm{MeOH}$ (4:1) to yield (-)-eschscholtzine $N$-oxide $(4,1.4 \mathrm{mg})$. Fraction F4 $(11.5 \mathrm{mg})$ was purified by preparative TLC eluted twice with $\mathrm{CHCl}_{3} / \mathrm{EtOH}$ (50:1 then 2:1) followed by $\mathrm{CH}_{2} \mathrm{Cl}_{2} / \mathrm{MeOH}$ (4:1) to yield (-)-reticuline $(0.8 \mathrm{mg})$ and $(+)-N$-methylcoculaurine $(1.0 \mathrm{mg})$.

\section{Antiproliferative Activity Assay}

The antiproliferative activity assay using sulforhodamine B (SRB) was performed as described previously. ${ }^{43}$ In brief, cells were seeded in 96-well microtiter plates at densities of 4000-12 000 cells per well (based on the doubling time of the cell line) with compounds solubilized in DMSO. The highest concentration of DMSO in the cultures $(0.1 \% \mathrm{v} / \mathrm{v})$ had no effect on cell growth. After $72 \mathrm{~h}$ treatment with test compounds, attached cells were fixed with $10 \%$ trichloroacetic acid followed by staining with $0.04 \%$ SRB. After solubilization of protein-bound SRB with $10 \mathrm{mM}$ Tris base, absorbance was measured at $515 \mathrm{~nm}$ using a microplate reader (ELx800, BioTek) with Gen5 software (BioTek). The mean $\mathrm{IC}_{50}$ is the average from at least three independent experiments with duplicate samples. The following human tumor cell lines were used in the assay: A549 (lung carcinoma), KB (originally isolated from epidermoid carcinoma of the nasopharynx), KB-VIN (VIN-resistant KB subline showing MDR phenotype by overexpressing P-gp), MCF-7 (estrogen receptorpositive, HER2-negative breast cancer), MDA-MB-231 (estrogen receptor-negative, progesterone receptor-negative, HER2-negative breast cancer). All cell lines were obtained from the Lineberger Comprehensive Cancer Center (UNC-CH) or from ATCC (Manassas, VA, USA), except KB-VIN, which was a generous gift of Professor Y.-C. Cheng (Yale University). KB-VIN cells were maintained in the presence of $100 \mathrm{nM}$ VIN.

\section{Cell Cycle Analysis}

Cell cycle distribution was analyzed by measurement of cellular DNA content with propidium iodide (BD Biosciences) as described previously. ${ }^{43}$ Briefly, cells were seeded in a 12-well culture plate $24 \mathrm{~h}$ prior to treatment with compounds. KB-VIN cells were treated for 24 h with 0.3 and $3.0 \mu \mathrm{M} \mathrm{1,} 20 \mu \mathrm{M} \mathrm{3}, 10 \mathrm{nM} \mathrm{CA}-4$, or vehicle (0.1\% DMSO) as a control. Stained cells were analyzed by flow cytometry (BD FACSCalibur, BD Biosciences). Experiments were repeated a minimum of three times.

\section{Immunofluorescence Staining}

Immunostaining of KB-VIN was performed as described previously. ${ }^{43}$ Briefly, KB-VIN cells were seeded on an eight-well chamber slide (Lab-Tech) for $24 \mathrm{~h}$ prior to treatment with compounds. Cells were treated with compound for $24 \mathrm{~h}$. Concentrations of reagents were 
used based on their $\mathrm{IC}_{50}$ used for cell cycle analysis as follows: 0.3 and $3.0 \mu \mathrm{M}$ of $1,20 \mu \mathrm{M}$ 3 , and $0.1 \%$ DMSO as a control. Cells were fixed in ice-cold $4 \%$ paraformaldehyde in phosphate-buffered saline (PBS) followed by permeabilization with $0.5 \%$ Triton X-100 in PBS. Fixed cells were labeled with mouse monoclonal antibody to a-tubulin (B5-1-2, Sigma) and rabbit polyclonal antibody to $\gamma$-H2AX (BETHYL Lab.) followed by FITCconjugated antibody to mouse IgG (Sigma) and Alexa Fluor 546-conjugated antibody to rabbit IgG (Life Technologies). Nuclei were labeled with DAPI (Sigma). Fluorescencelabeled cells were observed using a confocal microscope (Zeiss, LSM700) controlled by ZEN software (Zeiss). Parameters (laser, beam splitter, band-pass filter) for confocal fluorescence imaging were used as follows: track 1 for DAPI ( $405 \mathrm{~nm}, 420 \mathrm{~nm}, 420-1000$ nm), track 2 for FITC ( $488 \mathrm{~nm}, 544 \mathrm{~nm}, 490-555 \mathrm{~nm}$ ), and track 3 for Alexa Fluor 546 (555 $\mathrm{nm}, 559 \mathrm{~nm}, 505-600 \mathrm{~nm})$. Confocal images were reconstructed by stacking using ZEN (black edition) software (Zeiss). Final images were prepared by Photoshop CS6 (Adobe).

\section{Supplementary Material}

Refer to Web version on PubMed Central for supplementary material.

\section{Acknowledgments}

We appreciate critical comments, suggestions, and editing of the manuscript by Dr. S. L. Morris-Natschke (UNC$\mathrm{CH}$ ). We wish to thank the Microscopy Service Laboratory (UNC-CH) for confocal microscopy. This study was supported by a Grantin-Aid from the Ministry of Education, Culture, Sports, Science and Technology (JSPS KAKENHI, Japan) awarded to K.N.G. (Grant Numbers 25293024 and 25670054) and by a grant from the University Research Council (UNC) as well as the Eshelman Institute for Innovation, Chapel Hill, North Carolina, awarded to M.G. This work was also supported by NIH grant CA177584 from the National Cancer Institute, awarded to K.H.L. We also thank the Biological Testing Branch, DTP, DCTD, NCI, for performing the NCI 60-cell cytotoxicity assay and the Natural Products Support Group, Leidos Biomedical Inc., for plant extraction.

\section{References}

1. Bagchi R, Gallery RE, Gripenberg S, Gurr SJ, Narayan L, Addis CE, Freckleton EP, Lewis OT. Nature. 2014; 506:85-88. [PubMed: 24463522]

2. Wright SJ. Oecologia. 2002; 130:1-14. [PubMed: 28547014]

3. http://www.rainforestfoundation.org/home

4. Harvey AL, Edrada-Ebel R, Quinn RJ. Nat. Rev. Drug Discovery. 2015; 14:111-129. [PubMed: 25614221]

5. Newman DJ, Cragg GM. J. Nat. Prod. 2016; 79:629-661. [PubMed: 26852623]

6. Davis RA, Demirkiran O, Sykes ML, Avery VM, Suraweera L, Fechner GA, Quinn RJ. Bioorg. Med. Chem. Lett. 2010; 20:4057-4059. [PubMed: 20558060]

7. Yang BY, Kong LY, Wang XB, Zhang YM, Li RJ, Yang MH, Luo JG. J. Nat. Prod. 2016; 79:196203. [PubMed: 26741483]

8. Ren Y, Yuan C, Qian Y, Chai HB, Chen X, Goetz M, Kinghorn AD. J. Nat. Prod. 2013; 77:550-556. [PubMed: 24344605]

9. Chou TH, Chen JJ, Lee SJ, Chiang MY, Yang CW, Chen IS. J. Nat. Prod. 2010; 73:1470-1475. [PubMed: 20704331]

10. Feng R, Wang T, Wei W, Tan RX, Ge HM. Phytochemistry. 2013; 90:147-153. [PubMed: 23489577]

11. Huang W, Zhang WJ, Cheng YQ, Jiang R, Wei W, Chen CJ, Wang G, Jiao RH, Tan RX, Ge HM. Planta Med. 2014; 80:925-930. [PubMed: 25029174]

12. Allard PM, Dau ET, Eydoux C, Guillemot JC, Dumontet V, Poullain C, Canard B, Guéritte F, Litaudon M. J. Nat. Prod. 2011; 74:2446-2453. [PubMed: 22050318] 
13. Feng R, Guo ZK, Yan CM, Li EG, Tan RX, Ge HM. Phytochemistry. 2012; 76:98-105. [PubMed: 22277737]

14. Nehme CJ, de Moraes PLR, Tininis AG, Cavalheiro AJ. Biochem. Syst. Ecol. 2008; 36:602-611.

15. Cave A, Leboeuf M, Moskowitz H, Ranaivo A, Bick IRC, Sinchai W, Nieto M, Sevenet T, Cabalion P. Aust. J. Chem. 1989; 42:2243-2263.

16. Lee SS, Lin YJ, Chen CK, Liu KCS, Chen CH. J. Nat. Prod. 1993; 56:1971-1976.

17. Chang WT, Lee SS, Chueh FS, Liu KCS. Phytochemistry. 1998; 48:119-124.

18. Wu TS, Lin FW. J. Nat. Prod. 2001; 64:1404-1407. [PubMed: 11720521]

19. Lin FW, Wu PL, Wu TS. Chem. Pharm. Bull. 2001; 49:1292-1294. [PubMed: 11605656]

20. Lin FW, Wang JJ, Wu TS. Chem. Pharm. Bull. 2002; 50:157-159. [PubMed: 11848201]

21. Toribio A, Bonfils A, Delannay E, Prost E, Harakat D, Henon E, Richard B, Litaudon M, Nuzillard JM, Renault JH. Org. Lett. 2006; 8:3825-3828. [PubMed: 16898827]

22. Awang K, Hadi AHA, Saidi N, Mukhtar MR, Morita H, Litaudon M. Fitoterapia. 2008; 79:308310. [PubMed: 18313862]

23. Saidi N, Hadi AHA, Awang K, Mukhtar MR. Indian J. Chem. 2009; 9:461-465.

24. Saidi N. Jur. Nat. 2011; 11:48-51.

25. Nasrullah AA, Zahari A, Mohamad J, Awang K. Molecules. 2013; 18:8009-8017. [PubMed: 23884132]

26. Wan Othman WN, Liew SY, Khaw KY, Murugaiyah V, Litaudon M, Awang K. Bioorg. Med. Chem. 2016; 24:4464-4469. [PubMed: 27492195]

27. Hoffmann JJ, Luzbetak DJ, Torrance SJ, Cole JR. Phytochemistry. 1978; 17:1448.

28. Lee SS, Liu YC, Chen CH. J. Nat. Prod. 1990; 53:1267-1271.

29. Mollataghi A, Hadi AHA, Cheah SC. Molecules. 2012; 17:4197-4208. [PubMed: 22481540]

30. L ST, Lan PK. Yakugaku Zasshi. 1966; 86:177-184. [PubMed: 5948881]

31. Wu T, Lin F. J. Nat. Prod. 2001; 64:1404-1407. [PubMed: 11720521]

32. Urzua A, Mendoza L. J. Nat. Prod. 1986; 49:922-923.

33. Slavik J, Slavikova L. Collect. Czech. Chem. Commun. 1971; 36:2067-2069.

34. Youte JJ, Barbie D, Al-Mourabit A, Gnecco D, Marazano C. J. Org. Chem. 2004; 69:2737-2740. [PubMed: 15074921]

35. Johnson AP, Luke RWA, Singh G, Boa AN. J. Chem. Soc., Perkin Trans. 1. 1996; 9:907-913.

36. Capo M, Saa JM. J. Nat. Prod. 1989; 52:389-390.

37. Pinna GA, Cignarella G, Scolastico S, Porceddu ML. Eur. J. Med. Chem. 1994; 29:55-60.

38. Gellert E, Summons RE. Tetrahedron Lett. 1969; 58:5055-5058.

39. Ruiz-Olalla A, Wuerdemann MA, Wanner MJ, Ingemann S, Maarseveen JH, Hiemstra HJ. Org. Chem. 2015; 80:5125-5132.

40. Gellert E, Summons RE. Aust. J. Chem. 1970; 23:2095-2059.

41. Arndt RR. J. Chem. Soc. 1963:2547-2549.

42. Pereira MF, Rochais C, Dallemagne P. Anti-Cancer Agents Med. Chem. 2015; 15:1080-1091.

43. Nakagawa-Goto K, Oda A, Hamel E, Ohkoshi E, Lee KH, Goto M. J. Med. Chem. 2015; 58:2378. [PubMed: 25695315] 


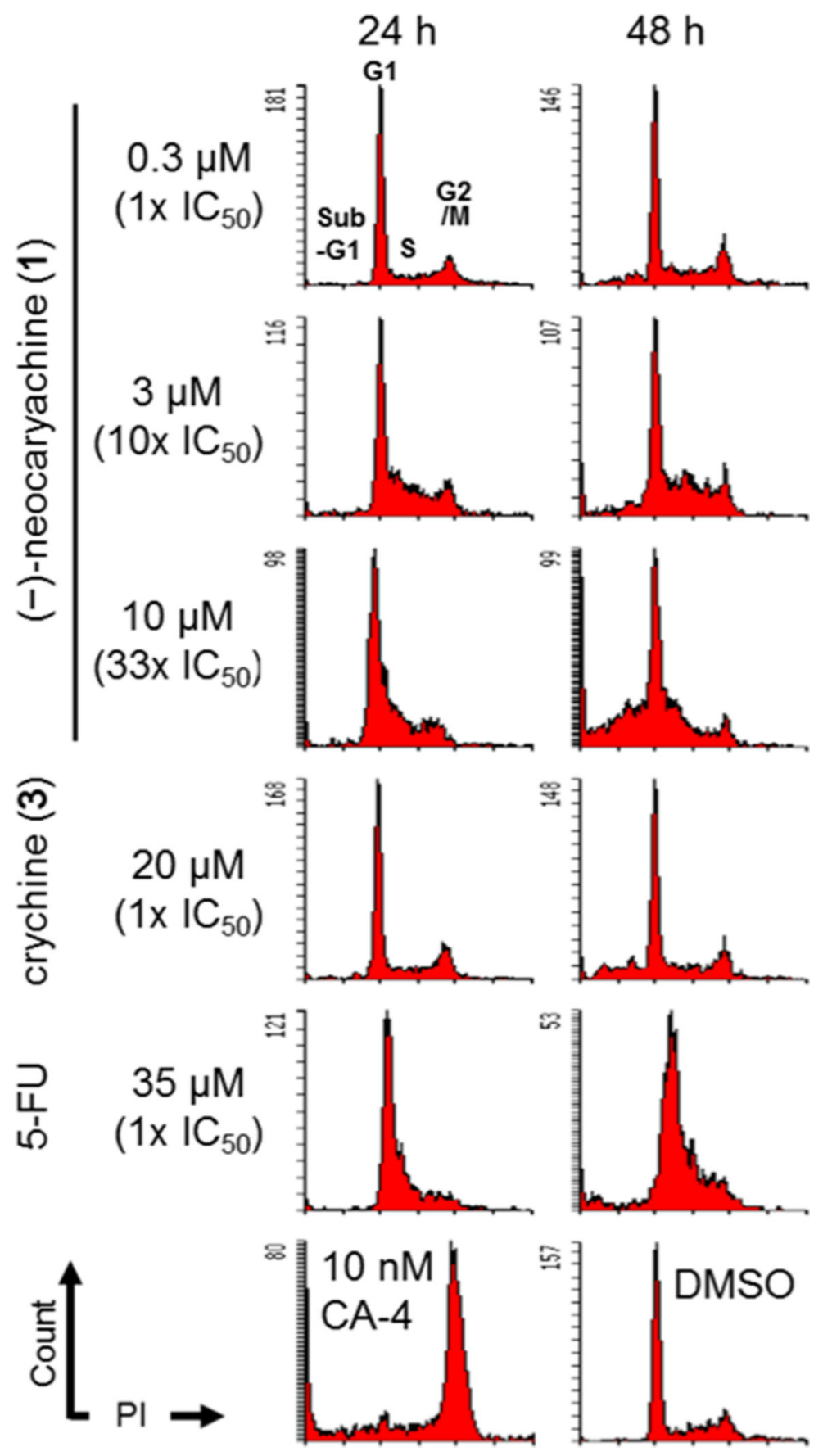

Figure 1.

Effects of (-)-neocaryachine (1) and crychine (3) on cell cycle progression in MDR cells. KBKB-VIN cells were treated with (-)-neocaryachine (1), crychine (3), or 5-FU for 24 or $48 \mathrm{~h}$ or CA-4 for $24 \mathrm{~h}$ at the indicated concentrations. DMSO was used as a vehicle control. Cell cycle distributions of treated cells were analyzed by flow cytometry after staining with propidium iodide $(\mathrm{PI})$. 

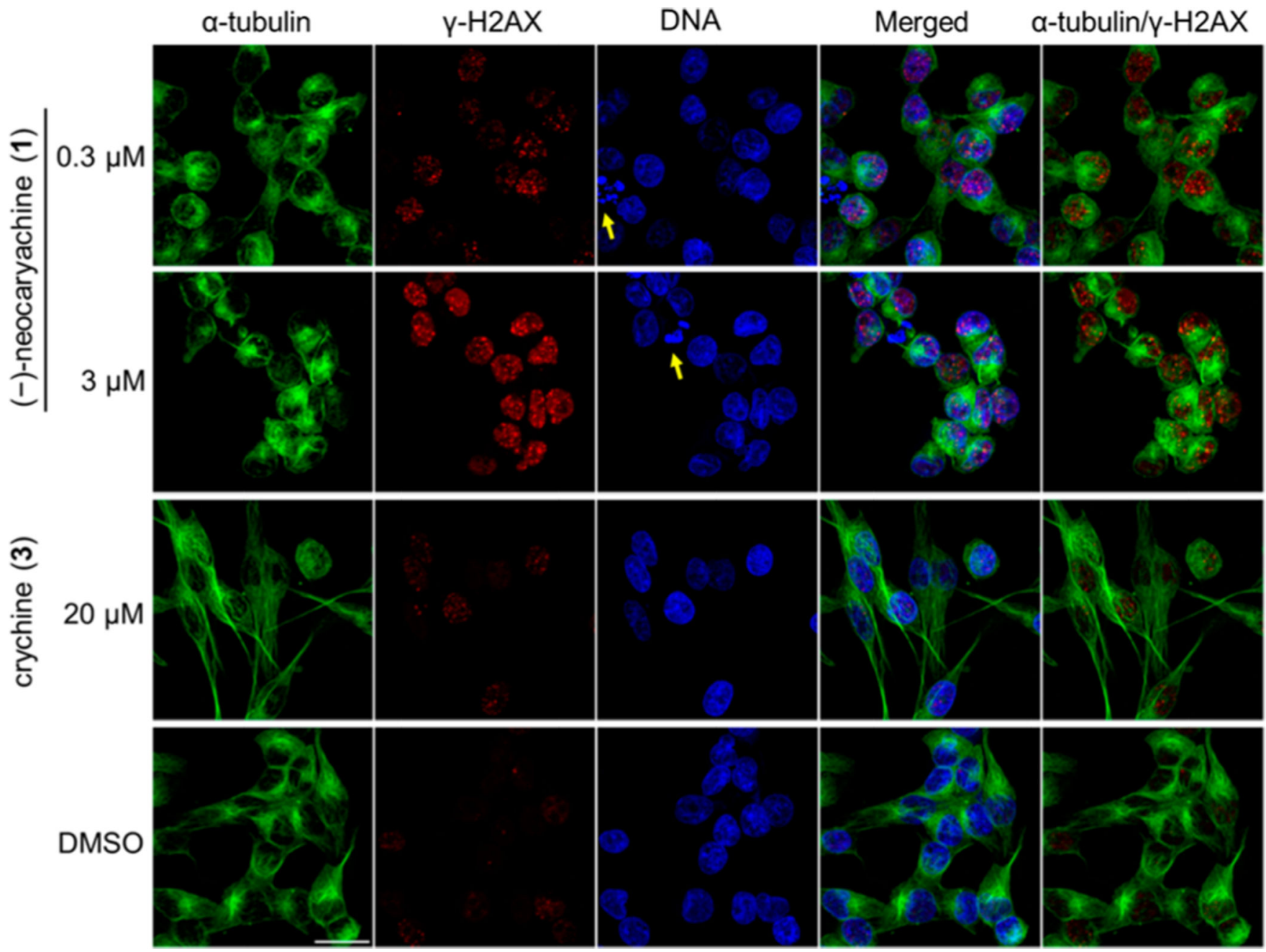

Figure 2.

Induction of $\gamma-\mathrm{H} 2 \mathrm{AX}$, a marker of DNA double-strand breaks, by (-)-neocaryachine (1) in MDR cells. KB-VIN cells were treated with (-)-neocaryachine (1) or crychine (3) for $24 \mathrm{~h}$ at the indicated concentrations. Cells were triple-stained with antibodies to a-tubulin (green), $\gamma$-H2AX (red), and DAPI (blue) for DNA. Stained cells were observed by confocal fluorescence microscopy, and all confocal images were stacked. Nuclear fragmentations are indicated by arrows. Bar: $25 \mu \mathrm{m}$. 
<smiles>[R2]c1cc2c(cc1[R2])[C@H]1Cc3cc([R5])c([R4])c([R3])c3[C@H](C2)N(C)C1</smiles>

Compounds

$1:(-)$-Neocaryachine

$2:(-)$-Isocaryachine

$3:(-)$-Crychine

$4:(-)$-Eschscholtzine- $N$-oxide

$5:(-)$-Norargemonine

6 : (-)-Bisnorargemonine
$\begin{array}{lllll}\mathrm{R}_{1} & \mathrm{R}_{2} & \mathrm{R}_{3} & \mathrm{R}_{4} & \mathrm{R}_{5}\end{array}$

$-\mathrm{O}-\mathrm{CH}_{2}-\mathrm{O}-\quad \mathrm{OH} \quad \mathrm{OMe} \quad \mathrm{H}$ $-\mathrm{O}-\mathrm{CH}_{2}-\mathrm{O}-\mathrm{H} \quad \mathrm{OMe} \quad \mathrm{OH}$ $-\mathrm{O}-\mathrm{CH}_{2}-\mathrm{O}-\quad \mathrm{H} \quad-\mathrm{O}-\mathrm{CH}_{2}-\mathrm{O}-$ $-\mathrm{O}-\mathrm{CH}_{2}-\mathrm{O}-\quad \mathrm{H} \quad-\mathrm{O}-\mathrm{CH}_{2}-\mathrm{O}-\quad \mathrm{N}$-oxide $\begin{array}{lllll}\mathrm{OMe} & \mathrm{OMe} & \mathrm{H} & \mathrm{OH} & \mathrm{OMe}\end{array}$ $\mathrm{OH} \quad \mathrm{OMe} \quad \mathrm{H} \quad \mathrm{OMe} \quad \mathrm{OH}$

Chart 1. Structures of Pavine Alkaloids Isolated from C. laevigata 

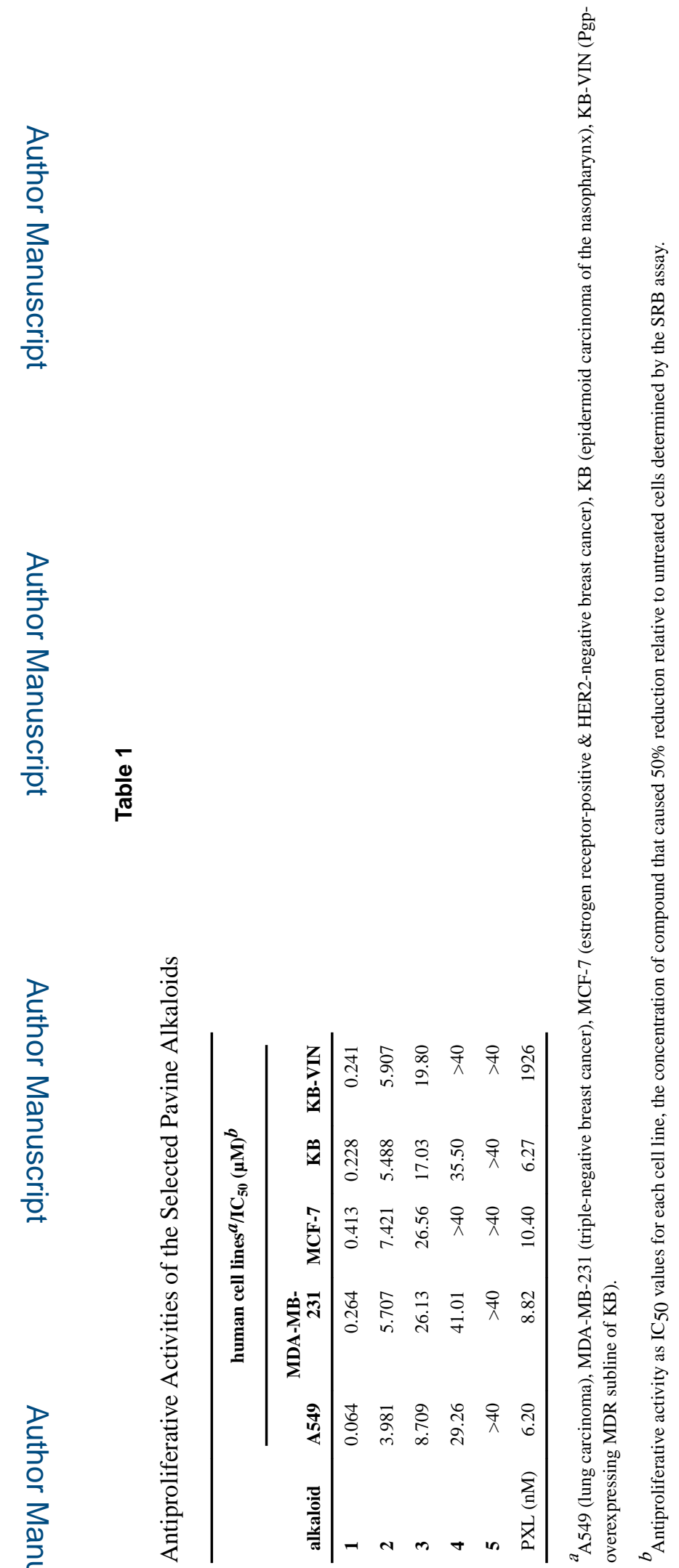

J Nat Prod. Author manuscript; available in PMC 2018 January 27. 